\title{
Antimicrobial effect of polyphenols from apple skins on human bacterial pathogens
}

\author{
María Rosa Alberto \\ Centro de Referencia para Lactobacilos (CERELA) \\ Chacabuco 145, San Miguel de Tucumán \\ Tucumán, Argentina \\ Tel: 543814310465 ext. 113-119 \\ Fax: 543814311720 \\ E-mail: ralberto@cerela.org.ar \\ Matías Andrés Rinsdahl Canavosio \\ Centro de Referencia para Lactobacilos (CERELA) \\ Chacabuco 145, San Miguel de Tucumán \\ Tucumán, Argentina \\ Tel: 543814310465 ext. 113-119 \\ Fax: 543814311720 \\ María Cristina Manca de Nadra* \\ Centro de Referencia para Lactobacilos (CERELA) \\ Chacabuco 145, San Miguel de Tucumán \\ Tucumán, Argentina \\ Tel: 543814310465 ext. 113 \\ Fax: 543814311720 \\ E-mail: mcmanca@fbqf.unt.edu.ar
}

Website: http://www.cerela.org.ar/metabolismo.htm

Financial support: Consejo de Investigaciones de la Universidad Nacional de Tucumán, Argentina (CIUNT), Consejo Nacional de Investigaciones Científicas y Técnicas (CONICET).

Keywords: bacterial inhibition, Granny Smith, Royal Gala, pathogens, phenolic extracts.

Apples possess many beneficial properties for the human health related with their high content in phenolic compounds. The antimicrobial effect of these compounds from the skin of two apple varieties, Royal Gala and Granny Smith, against human pathogens was examined. The phenolic compounds were extracted with the following solvents: A, acetone: water: acetic acid; B, ethyl acetate: methanol: water and $C$, ethanol: water. Total phenolic, flavonoid and non-flavonoid contents were analyzed in the extracts. The antimicrobial effect was determined using the agar diffusion method. The highest inhibitory effect of both apple varieties corresponded to extract $A$, which contained a high phenolic content. The Granny Smith extracts with higher phenolic content presented a superior antimicrobial effect against the selected microorganisms: Escherichia coli, Escherichia coli ATCC 25922, Escherichia coli ATCC 35218, Staphylococcus aureus ATCC 25923, Staphylococcus aureus ATCC 29213, Pseudomonas aeruginosa ATCC 27853, Enterococcus faecalis ATCC 29212 and Listeria monocytogenes. The most sensitive microorganisms were Escherichia coli ATCC 25922, Pseudomonas aeruginosa ATCC 27853 and Staphylococcus aureus ATCC 29213, whereas the most resistant strains were Escherichia coli ATCC 35218 and Escherichia coli. The results obtained demonstrate a direct relationship between the phenolic content of the extracts and the antimicrobial effect.

Apples are fruits consumed worldwide in different forms i.e. fresh, in juices and cider. Their beneficial properties to human health are related to the high content of phenol compounds.

Polyphenols are widely common secondary metabolites of plants, the content of which varies greatly between different species, and cultivars, and with maturity, season, region and yield. Polyphenols are classified according to their structure as phenolic acids derivates, flavonoids, and tannins. Apples contain many types of phenolic derivates and flavonoids (flavan-3-ols, flavonols, procyanidins, chalcones, and anthocyanins) (Mangas et al. 1999; Podsedek et al. 2000; Shoji et al. 2003).

*Corresponding author 
Apple pulp contains catechin, procyanidin, caffeic acid and chlorogenic acid among other components. The skin contains all the aforementioned substances as well as flavonoids, not present in pulp, such as quercetin glycosides and cyanidin glycosides (Escarpa and Gonzalez, 1998; Van der Sluis et al. 2001).

Epidemiological studies associate phenolic consumption with lower mortality, especially caused by coronary diseases. They present multiple biological properties, which are of growing interest for consumers due to the high antioxidant, anti-inflammatory, anti allergic, anti thrombosis and antimicrobial activities (Kanner et al. 1994; Frankel et al. 1995; Koga et al. 1999; Eberhardt et al. 2000; Jayaprakasha et al. 2003; Baydar et al. 2004; Shoji et. al. 2004). Furthermore they act as antideposit of triglyceride, anticholesterolemic, and antiviral agents among others. Phenolic compounds may affect microbial growth and metabolism (Alberto et al. 2001; Alberto et al. 2002; Alberto et al. 2004).

This paper studies the antimicrobial properties of phenolic compounds from apple skin of two varieties, Royal Gala and Granny Smith, against pathogenic bacteria to human beings.

\section{MATERIALS AND METHODS}

\section{Apples}

Two apple varieties, Royal Gala with a yellowish-red skin and Granny Smith with a greenish-white skin, were obtained from Tafí del Valle, Tucumán province, Argentina.

\section{Polyphenol extraction}

The peel of $6 \mathrm{~kg}$ of each apple variety was chopped up finely. Extractions were carried out twice for $8 \mathrm{hrs}$ at $60^{\circ} \mathrm{C}$ (Jayaprakasha et al. 2003) with $400 \mathrm{~mL}$ of the following solvents: A, acetone:water:acetic acid; B, ethyl acetate:methanol:water and C, ethanol:water. Extracts were then concentrated by drying in a rotatory evaporator at $35^{\circ} \mathrm{C}$ to avoid hydrolysis, redox and polymerization reactions that can alter the sample composition. Afterward, the concentrates were resuspended in $50 \mathrm{ml}$ methanol and kept at $-18^{\circ} \mathrm{C}$, avoiding direct contact with light and oxygen.

\section{Analytical determinations}

Total phenolic content was obtained with Folin-Ciocalteu reagent (Singleton and Rossi, 1965). The flavonoid fraction was obtained by mixing $10 \mathrm{~mL}$ of the extract with $10 \mathrm{ml}$ of diluted $\mathrm{HCl}(1: 3)$ and $5 \mathrm{ml}$ of an $8 \mathrm{mg} / \mathrm{mL}$ formaldehyde solution. The mixture was left to precipitate for $24 \mathrm{hrs}$ and then filtered. The non-flavonoid phenol contents were determined in the filtrate using Folin-Ciocalteu reagent. The flavonoid content was obtained by the difference between total phenol and non-flavonoid content. The phenol content is expressed as the equivalent of gallic acid per gram of apple skin (mg GAE/g). All determinations were carried out in triplicate.

\section{Extract clarification}

Clarification was carried out with $1 \mathrm{~g}$ of activated carbon in $20 \mathrm{ml}$ of each extract. Extracts were shaken and then membrane-filtered $(0.45 \mu)$. The clarified extracts without phenol compounds were used as negative controls in the antimicrobial activity assays. All extracts were filtersterilized $(0.22 \mu$ membrane $)$ and kept at $-18^{\circ} \mathrm{C}$.

\section{Microorganisms and culture media}

Escherichia coli, Escherichia coli ATCC 25922, Escherichia coli ATCC 35218, Staphylococcus aureus

Table 1. Phenolic contents in different extracts (A, B and C) from apple skin.

\begin{tabular}{|l|c|c|c|c|}
\hline \multirow{2}{*}{ Apple variety } & \multirow{2}{*}{ Extract } & \multicolumn{3}{|c|}{ Phenolic compounds } \\
\cline { 3 - 5 } & & Totals & Flavonoids & Non-Flavonoids \\
\hline \multirow{3}{*}{ Granny Smith } & A & $6.80^{*} \pm 0.15$ & $6.69 \pm 0.50$ & $0.11 \pm 0.09$ \\
\cline { 2 - 5 } & B & $5.08 \pm 0.08$ & $4.96 \pm 0.50$ & $0.12 \pm 0.04$ \\
\cline { 2 - 5 } & C & $3.02 \pm 0.08$ & $2.89 \pm 0.25$ & $0.13 \pm 0.10$ \\
\hline \multirow{2}{*}{ Royal Gala } & A & $3.49 \pm 0.14$ & $3.27 \pm 0.30$ & $0.22 \pm 0.02$ \\
\cline { 2 - 5 } & B & $1.99 \pm 0.08$ & $1.78 \pm 0.15$ & $0.21 \pm 0.05$ \\
\cline { 2 - 5 } & C & $2.60 \pm 0.13$ & $2.31 \pm 0.18$ & $0.29 \pm 0.16$ \\
\hline
\end{tabular}


Table 2. Effect of the apple skin extracts from Royal Gala and Granny Smith varieties against bacterial pathogens.

\begin{tabular}{|c|c|c|c|c|c|c|c|c|}
\hline Extracts & E coli & $\begin{array}{c}E \text { coli } \\
\text { ATCC25922 }\end{array}$ & $\begin{array}{c}E \text { coli } \\
\text { ATCC } 35218\end{array}$ & $\begin{array}{c}\text { S. aureus } \\
\text { ATCC } 25923\end{array}$ & $\begin{array}{c}\text { S. aureus } \\
\text { ATCC } 29213\end{array}$ & $\begin{array}{l}\text { P. aeruginosa } \\
\text { ATCC } \\
27853\end{array}$ & $\begin{array}{l}\text { E. faecalis } \\
\text { ATCC } \\
29212\end{array}$ & L. monocytogenes \\
\hline \begin{tabular}{l|l} 
Granny Smith & B \\
C
\end{tabular} & \begin{tabular}{l|c}
$\mathbf{A}$ & $6.0^{*}$ \\
$\mathbf{B}$ & 2.0 \\
$\mathbf{C}$ & -
\end{tabular} & $\begin{array}{l}7.0 \\
4.0 \\
4.0\end{array}$ & $\begin{array}{l}7.0 \\
- \\
-\end{array}$ & $\begin{array}{c}7.0 \\
2.0 \\
-\end{array}$ & $\begin{array}{c}10.0 \\
3.0 \\
1.0\end{array}$ & $\begin{array}{l}10 \\
3 \\
4\end{array}$ & $\begin{array}{l}9 \\
- \\
-\end{array}$ & $\begin{array}{l}9 \\
3 \\
-\end{array}$ \\
\hline $\begin{array}{ll}\text { Royal Gala } & \text { A } \\
\text { B } \\
\text { C }\end{array}$ & $\begin{array}{l}- \\
- \\
-\end{array}$ & $\begin{array}{l}4.0 \\
3.0 \\
2.0\end{array}$ & $\begin{array}{l}- \\
- \\
-\end{array}$ & $\begin{array}{l}3.0 \\
2.0 \\
1.0\end{array}$ & $\begin{array}{c}4.0 \\
2 \\
1\end{array}$ & $\begin{array}{l}4 \\
3 \\
-\end{array}$ & $\begin{array}{l}4 \\
- \\
-\end{array}$ & $\begin{array}{l}4 \\
3 \\
-\end{array}$ \\
\hline $\begin{array}{l}\text { Inhibition } \\
\text { zone } \\
\text { average }\end{array}$ & 1.3 & 4.0 & 1.2 & 2.5 & 3.5 & 4.0 & 2.2 & 3.2 \\
\hline $\begin{array}{c}\text { Control } \\
(+)\end{array}$ & 16 & 20 & 11 & 19 & 18 & 15 & 36 & 34 \\
\hline
\end{tabular}

A: acetone: water: acetic acid, B: ethyl acetate: methanol: water, C: ethanol: water. Control (+): $1 \mathrm{mg} / \mathrm{ml} \mathrm{Chloramphenicol.} \mathrm{Control} \mathrm{(-):}$ clarified

$\left(^{*}\right)$ Diameter of inhibition zone in $\mathrm{mm}$. Relative Standard Deviation (RSD) $\leq 0.5 \mathrm{~mm}$.

ATCC 25923, Staphylococcus aureus ATCC 29213 and Pseudomonas aeruginosa ATCC 27853 were cultured in common broth and Enterococcus faecalis ATCC 29212 and Listeria monocytogenes in BHI (Brain Heart Infusion).

\section{Antimicrobial activity}

Activity was measured using the agar diffusion method. Ten $\mathrm{ml}$ of soft agar $(0.75 \%)$ were mixture with $6.0 \times 10^{8}$ $\mathrm{cfu} / \mathrm{ml}$ of microorganism and then were sown on a Petri dish with $10 \mathrm{ml}$ of solidified culture medium (1.5\% agar). Dishes were left to solidify and little holes were punctured. Twenty $\mu \mathrm{l}$ of each extract was added to each hole and chloramphenicol $(1 \mathrm{mg} / \mathrm{ml})$ was used as positive control. Plates were incubated for $24 \mathrm{hrs}$ at $37^{\circ} \mathrm{C}$ for E. coli, S. aureus and $E$. faecalis and at $30^{\circ} \mathrm{C}$ for L. monocytogenes and $P$. aeruginosa. Analyses were carried out in triplicate with a precision of the inhibition zones of $0.5 \mathrm{~mm}$.

\section{Statistical analysis}

Statistical analysis was carried out using MS-Excel software.

\section{RESULTS AND DISCUSSION}

Table 1 reveals that the Granny Smith variety contained 49, 61 and 14\% more total polyphenols than Royal Gala (in extracts $\mathrm{A}, \mathrm{B}$ and $\mathrm{C}$ respectively). Moreover, flavonoid compounds were 51, 64 and 20\% higher than in Royal Gala (extracts $\mathrm{A}, \mathrm{B}$ and $\mathrm{C}$ respectively). In both varieties extract A contained the highest content of total phenol and flavonoid compounds.
Regarding the non-flavonoid fraction the content was very low compared to the total polyphenols: 2 to $4 \%$ for Granny Smith and 6 to $11 \%$ for Royal Gala.

Table 2 shows the effect of the different apple skin extracts on human bacterial pathogens. Clarified extracts, controls, did not show any antimicrobial effect. The mayor inhibitory effect for both varieties due to the phenolic compounds from the skin was observed in extract A, which contained the highest phenolic contents. E. coli ATCC 25922, P. aeruginosa ATCC 27853 and S. aureus ATCC 29213 were the most susceptible microorganisms, whereas E. coli ATCC 35218 and E. coli were the most resistant bacteria regarding the apple skin extracts.

The effect of identical concentrations (7 mg GAE/ml) of the apple skin extracts of both varieties on pathogenic bacteria is shown in Table 3. The controls, clarified extracts, did not show any antibacterial effect. These results confirm that extract A from Granny Smith was the most effective antibacterial agent. S. aureus ATCC 29213 and $P$. aeruginosa ATCC 27853 were the most susceptible microorganisms and E. coli and E. coli ATCC 35218 the most resistant bacteria.

Jayaprakasha et al. (2003) have reported the antimicrobial activity of acetone: water: acetic acid and methanol:water:acetic acid extracts from grape seed. Both extracts were active against Bacillus cereus, Bacillus coagulans, Bacillus subtilis, S. aureus, E. coli and $P$. aeruginosa. The authors evaluated the free radical scavenging activity of these extracts; the data obtained revealed that the extracts were free radical inhibitors and primary antioxidants that react with free radicals. They 
Table 3. Inhibitory effect of $7 \mathrm{mg} \mathrm{GAE} / \mathrm{ml}$ of skin extracts from Royal Gala and Granny Smithapples against bacterial pathogens.

\begin{tabular}{|c|c|c|c|c|c|c|c|c|c|}
\hline \multicolumn{2}{|l|}{ Extracts } & \multirow{2}{*}{$\begin{array}{c}\text { E coli } \\
\begin{array}{c}3.0^{*} \\
- \\
-\end{array}\end{array}$} & \multirow{2}{*}{$\begin{array}{c}\text { E coli } \\
\text { ATCC } \\
25922 \\
4.0 \\
2.0 \\
-\end{array}$} & \multirow{2}{*}{$\begin{array}{c}\text { E coli } \\
\text { ATCC } \\
35218 \\
3.5 \\
- \\
-\end{array}$} & \multirow{2}{*}{$\begin{array}{l}\text { S. aureus } \\
\text { ATCC } \\
25923 \\
4.0 \\
- \\
-\end{array}$} & \multirow{2}{*}{$\begin{array}{l}\text { S. aureus } \\
\text { ATCC } \\
29213 \\
4.5 \\
- \\
-\end{array}$} & \multirow{2}{*}{$\begin{array}{c}\text { P. aeruginosa } \\
\text { ATCC } \\
27853 \\
4.0 \\
- \\
1\end{array}$} & \multirow{2}{*}{$\begin{array}{l}\text { E. faecalis } \\
\text { ATCC } \\
29212 \\
5.0 \\
- \\
-\end{array}$} & \multirow{2}{*}{$\begin{array}{l}\text { L. monocytogenes } \\
\qquad \begin{array}{c}1.0 \\
- \\
-\end{array}\end{array}$} \\
\hline Granny Smith & $\begin{array}{l}\text { A } \\
\text { B } \\
\text { C }\end{array}$ & & & & & & & & \\
\hline Royal Gala & $\begin{array}{l}\text { A } \\
\text { B } \\
\text { C }\end{array}$ & $\begin{array}{l}- \\
-\end{array}$ & $\begin{array}{c}- \\
- \\
1.0\end{array}$ & $\begin{array}{l}- \\
- \\
-\end{array}$ & $\begin{array}{c}2.0 \\
1.0 \\
-\end{array}$ & $\begin{array}{l}3.0 \\
2.0 \\
2.0\end{array}$ & $\begin{array}{l}2.5 \\
1.0 \\
3.0\end{array}$ & $\begin{array}{l}2.5 \\
2.0 \\
1.0\end{array}$ & $\begin{array}{c}- \\
2.0 \\
1.0\end{array}$ \\
\hline \multicolumn{2}{|c|}{ Inhibition zone average } & 0.5 & 1.2 & 0.6 & 1.2 & 1.9 & 1.9 & 1.7 & 0.7 \\
\hline Control (+) & & 16 & 20 & 11 & 19 & 18 & 15 & 36 & 34 \\
\hline
\end{tabular}

A: acetone: water: acetic acid, B: ethyl acetate: methanol: water, C: ethanol: water. Control (+): 1 $\mathrm{mg} / \mathrm{ml}$ Chloramphenicol. Control (-): clarified extracts.

$\left({ }^{*}\right)$ Diameter of inhibition zone in $\mathrm{mm}$. Relative Standard Deviation (RSD) $\leq 0.5 \mathrm{~mm}$.

found that acetone:water:acetic acid extract was better radical scavenger than methanol:water:acetic extract.

Baydar et al. (2004) reported that acetone:water:acetic acid and ethyl acetate:methanol:water grape seed extracts inhibited the fifteen bacteria used as test organisms (Aeromonas hydrophila, B. brevis, $B$. cereus, $B$. megaterium, B. subtilis, E. faecalis, E. coli, Klebsiella pneumoniae, L. monocytogenes, Mycobacterium smegmatis, Proteus vulgaris, $P$. aeruginosa and S. aureus) and they attributed the inhibitory effect to their phenolic composition. The grape seed extracts had high total phenolics compared with those of bagasse (berry without seed and juice), which did not inhibit any of the bacteria tested. The authors attributed the inhibitory effect of the extracts to their phenolic composition.

Based on our results it may be concluded that the most effective extraction method for polyphenols from apples is with acetone:water:acetic acid. The Granny Smith extracts are more effective as antibacterial agents than those from Royal Gala. Moreover, there is a direct relationship between phenolic content and antibacterial effect.

The antibacterial effect of apple polyphenols demonstrated in this study can be added to the already known beneficial biological properties of these compounds to the human health, thus making this fruit even healthier.

\section{REFERENCES}

ALBERTO, M.R.; GÓMEZ-CORDOVÉS, C. and MANCA DE NADRA, M.C. Metabolism of gallic acid and catechin by Lactobacillus hilgardii from wine. Journal Agriculture Food Chemistry, October 2004, vol. 52, no. 21, p. 64656469.
ALBERTO, M.R.; FARÍAS, M.E. and MANCA DE NADRA, M.C. Effect of wine phenolic compounds on Lactobacillus hilgardii 5w viability. Journal of Food Protection, January 2002, vol. 65, no. 1, p. 211-213.

ALBERTO, M.R.; FARÍAS, M.E. and MANCA DE NADRA, M.C. Effect of gallic acid and catechin on Lactobacillus hilgardii 5w growth and metabolism of organic compounds. Journal Agriculture and Food Chemistry, September 2001, vol. 49, no. 9, p. 4359-4363.

BAYDAR, N.G.; ÖZKAN, G. and SAĞDIÇ, O. Total phenolic contents and antibacterial activities of grapes (Vitis vinifera L.) extracts. Food Control, July 2004, vol. 15 , no. 5 , p. 335-339.

EBERHARDT, M.V.; LEE, C.Y. and LIU, R.H. Antioxidant activity of fresh apples. Nature, June 2000, vol. 405, no. 6789, p. 903-904.

ESCARPA, A. and GONZALEZ, M.C. High-performance liquid chromatography with diode-array detection for the determination of phenolic compounds in peel and pulp from different apple varieties. Journal Chromatography, October 1998, vol. 823, no. 1-2, p. 331-337.

FRANKEL, E.N.; WATERHOUSE, A.L. and TEISSEDRE, P.L. Principal phenolic phytochemicals in selected California wines and their antioxidant activity in inhibiting oxidation of human low-density lipoproteins. Journal of Agricultural and Food Chemistry, April 1995, vol. 43 , no. 4 , p. $890-894$.

JAYAPRAKASHA, G.K.; SELVI, T. and SAKARIA, K.K. Antibacterial and antioxidant activities of grape (Vitis 
vinifera) seed extracts. Food Research International, June 2003, vol. 36, no. 2, p. 117-122.

KANNER, J.; FRANKEL, E.; GRANIT, R.; GERMAN, B. and KINSELLA, J.E. Natural antioxidants in grapes and wine. Journal of Agricultural and Food Chemistry, January 1994, vol. 42, no. 1, p. 64-69.

KOGA, T.; MORO, K.; NAKAMORI, K.; YAMAKOSHI, J.; HOSOYAMA, H.; KATAOKA, S. and ARIGA, T. Increase of antioxidative potential of rat plasma by oral administration of proanthocyanidin-rich extract from grape seeds. Journal of Agricultural and Food Chemistry, May 1999, vol. 47, no. 5, p. 1892-1897.

MANGAS, J.J.; RODRÍGUEZ, R.; SUAREZ, B.; PICINELLI, A. and DAPENA, E. Study of the phenolic profile of cider apple cultivars at maturity by multivariate techniques. Journal of Agricultural and Food Chemistry, October 1999, vol. 47, no. 10, p. 4046-4052.

PODSEDEK, A.; WILSKA-JESKA, J.; ANDERS, B. and MARKOWSKI, J. Compositional characterization of some apple varieties. Europea Food Research Technology, February 2000, vol. 210, no. 4, p. 268-272.

SHOJI, T.; AKAZOME, Y.; KANDA, T. and IKEDA M. The toxicology and safety of apple polyphenol extract. Food and Chemical Toxicology, June 2004, vol. 42, no. 6, p. 959-967.

SHOJI, T.; MUTSUGA, M.; NAKAMURA, T.; KANDA, T.; AKIYAMA, H. and GODA, Y. Isolation and structural elucidation of some procyanidins from apple by lowtemperature NMR. Journal of Agricultural and Food Chemistry, June 2003, vol. 51, no. 13, p. 3806-3813.

SINGLETON, V.L. and ROSSI, J.A. Jr. Colorimetry of total phenolics with phosphomolybdic phosphotungstic acid reagents. American Journal Enology and Viticulture, September 1965, vol. 16, no. 1, p. 144-158.

VAN DER SLUIS, A.A.; DEKKER, M.; DE JAGER, A. and JONGEN, W.M.F. Activity and concentration of polyphenolic antioxidants in apple: effect of cultivar, harvest year, and storage conditions. Journal of Agricultural and Food Chemistry, August 2001, vol. 49, no. 8, p. 3606-3613. 